\title{
Opinion \& Special Article: Next Steps in Palliative Care Education for Neurology Residents
}

Tara Cook, MD, Robert Arnold, MD, Kwonho Jeong, MS, and Julie Childers, MD

Neurology ${ }^{\circledR}$ 2021;97:1134-1137. doi:10.1212/WNL.0000000000012911
Correspondence

Dr. Childers

childersjw2@upmc.edu

\begin{abstract}
Many neurologic diseases are life limiting and markedly impair patients' quality of life. Growing recommendations in the field recommend that neurologists have primary skills in palliative medicine that will allow them to manage symptoms and discuss end-of-life decisions with patients and families. Previous work has shown that formal palliative care training in neurology residencies is very limited. In this article, we briefly describe a national survey of neurology residents where we assess both the quantity and quality of the teaching they receive in end-of-life care as compared to a common and an uncommon neurologic condition. Based on the gaps we identified, as well as previous studies and recommendations in neuropalliative care, we provide 9 recommendations to help neurology residency programs improve their teaching of primary neuropalliative care skills.
\end{abstract}

\section{Introduction}

Many neurologic diseases are life limiting and impair quality of life. Cerebrovascular disease, dementia, and Parkinson disease are respectively the third, fifth, and twelfth leading causes of death for older adults. ${ }^{1}$ Palliative care (PC), often provided by specialists, is an approach to care in serious illness that focuses on quality of life and communication. Neurology patients and their caregivers express a desire to receive PC and demonstrate unmet PC needs. ${ }^{2,3}$ Given the shortage of trained PC clinicians, it is recommended that neurologists learn certain essential PC skills. These skills, termed primary PC, include providing relief from pain and/or other distressing symptoms, integrating psychological and spiritual aspects of care, assisting with difficult decision making, and supporting patients and families. Current Accreditation Council for Graduate Medical Education milestones and entrustable professional activities list "lead a family meeting" and "palliate patients with advanced neuromuscular diseases" as primary PC skills that every graduating neurology resident should possess. ${ }^{4}$

Formal training in PC is variable in neurology residencies. A survey of program directors found that $42 \%$ were not satisfied with PC education available in their programs, citing faculty expertise and time for teaching as barriers. ${ }^{5}$ In another national study, neurology residents answering a 5-question objective PC knowledge test got $44 \%$ correct. ${ }^{6}$ We still know little about whether the PC teaching neurology residents receive is high quality (i.e., incorporates principles of adult learning, including being interactive, cased-based, and incorporating feedback). We therefore conducted an online national survey of fourth-year adult neurology residents to determine the type and quality of teaching in PC they received during their residencies, as compared to teaching in other neurologic disorders, and their self-assessed preparedness in neuropalliative domains vs other skills in neurology. Below we briefly describe the survey results and provide recommendations for next steps in PC training in neurology residencies. 


\section{Glossary}

EMG = electromyogram; $\mathbf{P C}=$ palliative care.

\section{Methods}

The survey (eAppendix 1, links.lww.com/WNL/B603) asked about experiences in caring for patients within the last 12 months of life as compared to a common neurologic disorder (stroke) and an uncommon neurologic disorder (temporal arteritis). We used a 5-point Likert scale for all responses except the assessment of attitudes, for which we used a 6-point scale; we also included a free text question "In your opinion, what one change would most improve end-of-life care education for residents in Neurology?" Descriptive statistics (mean and SDs) were calculated for each item. The free text question was grouped into themes by the first author (T.C.). The University of Pittsburgh Institutional Review Board determined this study exempt.

\section{Results}

Of 133 adult neurology programs in the United States, we were able to send the survey directly to residents in 36 programs (201 residents). Sixty programs agreed to forward our email to their residents (323 residents). Ninety-nine neurology residents completed the survey. Respondents felt that it was very important or essential for them to learn to provide care for patients at the end of life (4.3). Eight-nine (90\%) of the respondents reported receiving some PC education. Types of PC training included observing senior team members have end-oflife discussions (90\%), having a senior team member observe them lead end-of-life discussions (68\%), lecture (60\%), informal role playing (24\%), simulated or standardized patent interactions (7\%), online education including webinars (3\%), and $\mathrm{PC}$ rotations as an intern (5\%).

Residents reported less quantity and quality of teaching in endof-life patient management of neurologic disease compared with the management of a common neurologic disorder (stroke) (4.7). They receive the same quantity of teaching in the management of an uncommon neurologic disorder (temporal arteritis) as they do in the end-of-life patient management of neurologic disease (3.8); however, they receive a lower quality of teaching end-of-life patient management of neurologic disease (3.1).

Relative to common and uncommon neurologic disorders, residents also receive less mentoring in end-of-life care (acute stroke [4.7], temporal arteritis [3.8], vs management of patients at end of life [3.4]). Compared with management of acute stroke, this difference in mentoring and role modeling was present for both communication skills (3.7) and symptom management (3.2). For example, residents perform more family meetings (4.2) than they do electromyograms (EMGs), a common neurologic procedure (3.2) but receive more observation (4.7) and feedback (4.7) by attendings or fellows following EMG compared with the observation of (3.1) or feedback received (2.7) following family meetings.

In terms of self-assessed preparedness, residents felt less prepared to manage a patient at end of life (3.3) than to manage stroke (4.3). Of interest, the residents felt better prepared in terms of palliative communication skills (3.6) than in providing symptom management (3.0).

Resident response to the free text question indicated that neurology residents want more specialized training in PC (Table). In particular, despite the fact that on average, residents had rated their communication skills highly, many desired more communication skills training during residency.

\section{Discussion}

We found that, similar to previous work, more education in neuropalliative care is needed in residency training. Our study showed that training in neuropalliative care was similar in quantity to what is provided for an uncommon neurologic condition and lower in quality. Although most residents reported receiving some PC teaching or mentoring, this was mostly in the form of observing their attending lead a family meeting (90\%) or being observed leading a family meeting themselves $(68 \%)$. The fact that residents rated the amount of formal feedback they had received about how to run a family meeting as low and that they requested more formal teaching and debriefing about communication in their comments suggests that such feedback is uncommon. Passive learning-observation or lectures without the opportunity for debriefing, assessment, or deliberate practice with feedback-is lower quality and less likely to result in behavior change.

Our response rate of $19 \%$ limits interpretation of our results. Our sample may have been biased, as residents who perceived a lack of PC teaching might have been more likely to respond; conversely, programs that did not value PC may have been less likely to distribute the survey to residents. However, our results were similar to the earlier findings of Mehta, whose survey of program directors found that adult neurology residents have limited opportunities for education in PC, and $20 \%$ of neurology residency programs provide no palliative training at all-in our survey, $10 \%$ of residents had no palliative education, a slight improvement. We note that we included only adult neurology residents in the survey; it is likely 
Table Neurology Resident Responses to "In your opinion, What One Change Would Most Improve End-of-Life Care Education for Residents in Neurology?" ( $n=69)$ and Associated Recommendations for Primary Palliative Care Education in Neurology Residencies

\begin{tabular}{|c|c|c|c|}
\hline Broad category & Subcategory & Example quotation & $\begin{array}{l}\text { Related } \\
\text { recommendation(s) }\end{array}$ \\
\hline \multirow{3}{*}{$\begin{array}{l}\text { Specialized } \\
\text { palliative care } \\
\text { training }\end{array}$} & $\begin{array}{l}\text { Hands on management } \\
\text { of end-of-life symptoms }\end{array}$ & $\begin{array}{l}\text { "More formal and hands on training in the topic. Also, more comfort with } \\
\text { prescribing benzos for air hunger and anxiety in end-of-life care" }\end{array}$ & 2 \\
\hline & Didactics & $\begin{array}{l}\text { "Lectures from palliative care physicians." } \\
\text { "I would like to see more training involving residents' sensitivity to these issues and } \\
\text { also address their own feeling concerning palliative care and end-of-life issues." }\end{array}$ & $\begin{array}{l}2 \\
3\end{array}$ \\
\hline & Rotations & "Incorporation of palliative care rotations for neurology residents." & 5 \\
\hline \multirow[t]{4}{*}{$\begin{array}{l}\text { Communication } \\
\text { training }\end{array}$} & Observe faculty & $\begin{array}{l}\text { "Ensuring that trainees observe faculty perform as many meetings as possible and } \\
\text { then debrief to learn new techniques." }\end{array}$ & 8 \\
\hline & Simulation & "...have the opportunity to test skills on simulated patients." & 1 \\
\hline & Feedback & $\begin{array}{l}\text { "Having attendings be more present in these end of life discussions, even if the } \\
\text { resident or fellow does the talking. Since my first year of residency, most times, I } \\
\text { was having these conversations by myself... Many times the neurology attending } \\
\text { wouldn't be there, which made it challenging to learn from observing them and } \\
\text { also challenging in terms of getting feedback about how the family meeting went." }\end{array}$ & $6,7,8$ \\
\hline & Uncertainty of prognosis & $\begin{array}{l}\text { "A better understanding and training on how to counsel patients on our deep } \\
\text { uncertainty of how they will do... I struggle personally with counseling patients that } \\
\text { their loved one is dying but that we have no idea how long it might really take for } \\
\text { them to die or how comfortable they will/won't be." }\end{array}$ & $2,4,5$ \\
\hline \multirow[t]{3}{*}{ Barriers } & Making time & $\begin{array}{l}\text { "A way to set aside time and make a priority of family discussions and goals of care } \\
\text { conversations, such as that they don't get pushed to the bottom of the to-do list." }\end{array}$ & 6 \\
\hline & $\begin{array}{l}\text { Faculty not present to } \\
\text { observe }\end{array}$ & "...more attending observation of residents leading end-of-life discussions." & 6 \\
\hline & Lack of exposure & $\begin{array}{l}\text { "Actively participating in multiple aspects of end of life care including spending time } \\
\text { with a patient that is on hospice (not one who is simply terminally extubated), } \\
\text { rounding with a palliative care team and being present to administer medications } \\
\text { at end of life more than simply learning to run a family meeting" }\end{array}$ & 4,5 \\
\hline \multirow[t]{2}{*}{$\begin{array}{l}\text { Formal } \\
\text { requirement }\end{array}$} & Rotation & $\begin{array}{l}\text { "I think having a more dedicated and formal instruction in palliative care and } \\
\text { opportunities to do rotations would be a wonderful and positive change." }\end{array}$ & 4,5 \\
\hline & Clinical skills evaluation & $\begin{array}{l}\text { "Palliative Care Clinical Skills Assessment for the Clinical Skills Evaluation section } \\
\text { through ABPN resident certification." }\end{array}$ & 9 \\
\hline
\end{tabular}

${ }^{\text {a }}$ Recommendation number(s) as listed in the text.

that there are similar educational gaps in child neurology programs, but this requires further study.

This survey suggests some directions for PC training in neurology. The most frequent types of education reported were observation (90\%) and lectures (60\%). Respondents particularly highlighted the need for active learning, with observed practice, debriefing, and feedback. This is consistent with what we know of adult learning principles. ${ }^{7}$ Residents learn best when learning is interactive, involves feedback, and case based. Therefore, neurology programs should include structured, active training in neuropalliative care, and residents' learning in this area should be reinforced with assessment and feedback. This is doable-residency programs in other specialties have developed innovative methods to include active teaching of primary PC skills-including simulated patient practice, interactive online modules, and coaching. ${ }^{8-10}$
Based on these results, as well as previous work and growing experience in neuropalliative care, ${ }^{11-13}$ we recommend the following steps to improve education in primary PC for neurology residents. Many programs may already include some of these elements-and our results make clear that not all do. We hope that these suggestions provide ideas for improvement to even the innovative training programs.

1. Develop simulated patient training to teach residents how to respond to emotion, give bad news, and discuss goals of care, similar to that which has been developed in other specialties.

2. When discussing neurologic diseases that are progressive and/or incurable, include review of palliative aspects in case discussions, including symptom management and caregiver issues.

3. Give neurology residents the resources to debrief end-oflife cases that are emotionally difficult. 
4. Identify PC champions within neurology faculty to collaborate with PC faculty to develop education for neurology residents.

5. Offer neurology residents rotations in inpatient palliative medicine.

6. Provide faculty development in PC to neurology attendings, particularly emphasizing a structured approach to family meetings and how to teach family meeting skills.

7. Provide faculty development to improve teaching skills, including how to teach interactively and how give feedback to residents.

8. Teach family meetings as procedures, with dedicated time, debriefing, and feedback.

9. Finally, to emphasize the importance of PC domains in neurology, residencies, as part of their clinical skills assessment and evaluation of milestones, should evaluate residents' competencies in these domains:

- Giving serious news and discussing prognosis

- Leading family meetings

- Symptom management

- Navigating care for patients with advanced illness

Most treatments neurologists offer are palliative rather than curative. By attending to the palliative aspects of neurologic diseases, neurologists can improve the quality of life of patients. Increasing the amount and quality of education and assessment of PC skills in neurology residencies will benefit patients.

\section{Acknowledgment}

First author Tara Cook is deceased.

\section{Study Funding}

No targeted funding reported.

\section{Disclosure}

$\mathrm{R}$. Arnold is on the board of VitalTalk, is the editor of PCFACS for the American Academy of Hospice and Palliative Medicine, and is an associate editor for UpToDate. J. Childers discloses personal fees from VitalTalk. K. Jeong has no disclosures. Go to Neurology.org/N for full disclosures.
Appendix Authors

\begin{tabular}{|c|c|c|}
\hline Name & Location & Contribution \\
\hline $\begin{array}{l}\text { Tara Cook, } \\
\text { MD }\end{array}$ & $\begin{array}{l}\text { University of } \\
\text { Pittsburgh, PA }\end{array}$ & $\begin{array}{l}\text { Drafting/revision of the manuscript for } \\
\text { content, including medical writing for } \\
\text { content; major role in the acquisition of } \\
\text { data; study concept or design; and analysis } \\
\text { or interpretation of data }\end{array}$ \\
\hline $\begin{array}{l}\text { Robert } \\
\text { Arnold, } \\
\text { MD }\end{array}$ & $\begin{array}{l}\text { University of } \\
\text { Pittsburgh, PA }\end{array}$ & $\begin{array}{l}\text { Drafting/revision of the manuscript for } \\
\text { content, including medical writing for } \\
\text { content; major role in the acquisition of } \\
\text { data; study concept or design; and analysis } \\
\text { or interpretation of data }\end{array}$ \\
\hline $\begin{array}{l}\text { Kwonho } \\
\text { Jeong, MS }\end{array}$ & $\begin{array}{l}\text { University of } \\
\text { Pittsburgh, PA }\end{array}$ & Analysis or interpretation of data \\
\hline $\begin{array}{l}\text { Julie } \\
\text { Childers, } \\
\text { MD }\end{array}$ & $\begin{array}{l}\text { University of } \\
\text { Pittsburgh, PA }\end{array}$ & $\begin{array}{l}\text { Drafting/revision of the manuscript for } \\
\text { content, including medical writing for } \\
\text { content; major role in the acquisition of } \\
\text { data; study concept or design; and analysis } \\
\text { or interpretation of data }\end{array}$ \\
\hline
\end{tabular}

\section{References}

1. Centers for Disease Control. Underlying cause of death, 1999-2019. Available at: wonder.cdc.gov/. Accessed March 8, 2021.

2. Liu Y, Kline D, Aerts S, et al. Inpatient palliative care for neurological disorders: lessons from a large retrospective series. J Palliat Med. 2017;20(1):59-64.

3. Boersma I, Jones J, Carter J, et al. Parkinson disease patients' perspectives on palliative care needs: what are they telling us? Neurol Clin Pract. 2016;6(3):209-219.

4. American Council for Graduate Medical Education. ACGME Program Requirements for Graduate Medical Education in Neurology. Accessed March 14, 2021. www. acgme.org/Portals/0/PFAssets/ProgramRequirements/180_Neurology_2020.pdf? ver $=2020-02-25-140549-567$.

5. Mehta AK, Najjar S, May N, Shah B, Blackhall L. A needs assessment of palliative care education among the United States adult neurology residency programs. J Palliat Med. 2018;21(10):1448-1457.

6. Creutzfeldt CJ, Gooley T, Walker M. Are neurology residents prepared to deal with dying patients? Arch Neurol. 2009;66(11):1427-1428.

7. Reed S, Shell R, Kassis K, et al. Applying adult learning practices in medical education. Curr Probl Pediatr Adolesc Health Care. 2014;44(6):170-1781.

8. Rodenbach R, Kavalieratos D, Tamber A, et al. Coaching palliative care conversations: evaluating the impact on resident preparedness and goals-of-care conversations. J Palliat Med. 2020;23(2):220-225.

9. Schell JO, Cohen RA, Green JA, et al. Nephrotalk: evaluation of a palliative care communication curriculum for nephrology fellows. J Pain Symptom Manage. 2018;56(5):767-773.e2.

10. Moody K, McHugh M, Baker R, et al. Providing pediatric palliative care education using problem-based learning. J Palliat Med. 2018;21(1):22-27.

11. Brizzi K, Creutzfeldt CJ. Neuropalliative care: a practical guide for the neurologist. Semin Neurol. 2018;38(5):569-575.

12. Creutzfeldt CJ, Kluger B, Kelly AG, et al. Neuropalliative care: priorities to move the field forward. Neurology. 2018;91(5):217-226.

13. Boersma I, Miyasaki J, Kutner J, Kluger B. Palliative care and neurology: time for a paradigm shift. Neurology. 2014;83(6):561-567.

\section{Manage Your Career | Recruit Top Talent}

The AAN's Neurology Career Center is the largest job site specifically for neurologists. Visit careers.aan.com to find your next hire or search from hundreds of open positions in neurology. 


\section{Neurology}

\section{Opinion \& Special Article: Next Steps in Palliative Care Education for Neurology Residents}

Tara Cook, Robert Arnold, Kwonho Jeong, et al.

Neurology 2021;97;1134-1137 Published Online before print October 5, 2021

DOI 10.1212/WNL.0000000000012911

This information is current as of October 5, 2021

\section{Updated Information \& Services}

References

Citations

Subspecialty Collections

Permissions \& Licensing

Reprints including high resolution figures, can be found at: http://n.neurology.org/content/97/24/1134.full

This article cites 11 articles, 3 of which you can access for free at: http://n.neurology.org/content/97/24/1134.full\#ref-list-1

This article has been cited by 1 HighWire-hosted articles: http://n.neurology.org/content/97/24/1134.full\#\#otherarticles

This article, along with others on similar topics, appears in the following collection(s):

\section{All Education}

http://n.neurology.org/cgi/collection/all_education

Methods of education

http://n.neurology.org/cgi/collection/methods_of_education

Palliation pain

http://n.neurology.org/cgi/collection/palliation_pain

Information about reproducing this article in parts (figures,tables) or in its entirety can be found online at:

http://www.neurology.org/about/about_the_journal\#permissions

Information about ordering reprints can be found online:

http://n.neurology.org/subscribers/advertise

Neurology ${ }^{\circledR}$ is the official journal of the American Academy of Neurology. Published continuously since 1951, it is now a weekly with 48 issues per year. Copyright (C 2021 American Academy of Neurology. All rights reserved. Print ISSN: 0028-3878. Online ISSN: 1526-632X.

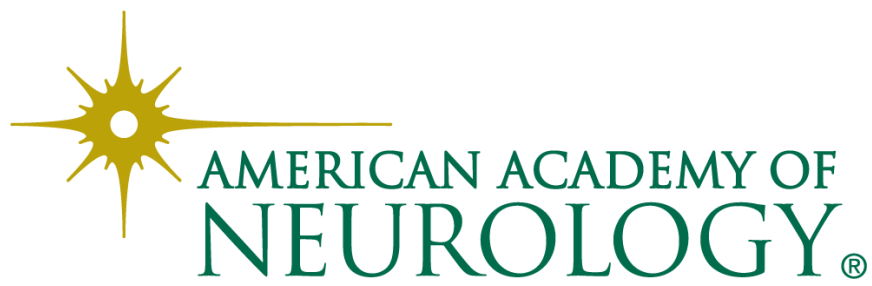

